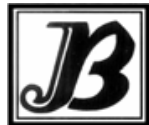

J. bio-sci. 14: 139-141, 2006

ISSN 1023-8654

-Short Communication

\title{
LENGTH-WEIGHT RELATIONSHIP, CONDITION FACTOR AND SEX-RATIO OF FRESHWATER FISH, RHINOMUGIL CORSULA (HAMILTON) (MUGILIFORMES: MUGILIDAE) FROM RAJSHAHI, BANGLADESH
}

\author{
M Golam Mortuza and Tawfeequa Rahman \\ Department of Zoology, Rajshahi University, Rajshahi 6205, Bangladesh
}

Rhinomugil corsula (Hamilton) is a small indigenous fish of Bangladesh. This fish is praised for its taste, and commonly called as Khorsula, Ural, etc., and is abundantly found in the inland water bodies of Bangladesh (Rahman 1989). Due to destruction of the natural habitat and other factors, population of this species became threatened (Khan 2000). Published report on the length-weight relationship is important for the studies on biology, population and management of species and their fisheries (Le Cren 1951, Shafi and Quddus 1974). The present investigation is concerned with the study of size frequency distribution, lengthweight relationship, condition factor, relative condition factor and sex-ratio of $R$. corsula at Rajshahi area.

A total of 1200 specimens of $R$. corsula were randomly collected from December 1995 to November 1996 from different fish markets of Rajshahi city. The monthly collections were sexed and size grouped (18 size groups with $10 \mathrm{~mm}$ class intervals). The males were found to be ranged from 87 to $256 \mathrm{~mm}$ in total length and the total weights were found to be ranged from 6.0 to $189.6 \mathrm{~g}$. In case of female, the total length and total weight were ranged between from 86 to $267 \mathrm{~mm}$ and 7.2 to $198.3 \mathrm{~g}$ respectively. The mean total length for male was calculated as $170.236 \pm 51.774 \mathrm{~mm}$ and the mean total weight calculated as $57.238 \pm 47.708 \mathrm{~g}$ $(\mathrm{N}=534)$. For female, the mean total length and total weight were calculated as $175.315 \pm 56.241 \mathrm{~mm}$ and $66.667 \pm 59.061 \mathrm{~g}(\mathrm{~N}=666)$ respectively.

The length-weight relationships were calculated as:

$\log W=-4.914 \pm 2.941 \log L, r=0.936$ (male)

$\log W=-5.052 \pm 3.008 \log L, r=0.934$ (female)

$\log W=-4.997 \pm 2.984 \log L, r=0.937$ (combined)

Hile (1936) and Martin (1949) observed that the value of the regression coefficient " $n$ " usually lies between 2.5 and 4.0 and for ideal fish maintain the shape $n=3$. The values of regression coefficient for male (2.941), female (3.008) and combined sexes (2.984) in the present analysis are very much closed to 3.0 and therefore, $R$. corsula does follow the cube law.

The condition factor or Ponderal index, or co-efficient of correlation expresses the condition of a fish, such as the degree of well being, relative robustness, plumpness or fatness in numerical terms. The condition factor 
was determined from observed total weights and calculated weights. For the observed weights the condition factor $(K)$ ranged from 0.8395 to 1.1176 with a mean of $0.9155 \pm 0.0626$ (male), in female 0.8695 to 1.1138 with a mean of $0.9320 \pm 0.1060$ and in combined sexes it ranged from 0.8151 to 1.1153 with a mean of $0.9373 \pm 0.0803$. The mean calculated condition factor $(\mathrm{k})$ was $0.9038 \pm 0.0175$ with a range of 0.8826 to 0.9373 for male. For female, the mean calculated condition factor was $0.9245 \pm 2.3399$ with a range from 0.92 to 0.9279 . In case of combined sexes, it was $0.9462 \pm 0.0625$ with a range of 0.9159 to 1.2061.

Table 1. Month-wise distribution of male and female of $R$. corsula.

\begin{tabular}{|c|c|c|c|c|c|c|c|c|c|c|c|c|c|}
\hline Month & Dec & Jan & Feb & Mar & Apr & May & Jun & Jul & Aug & Sep & Oct & Nov & $\begin{array}{c}\text { Grand } \\
\text { Total }\end{array}$ \\
\hline Male & 69 & 55 & 38 & 180 & 60 & 18 & 19 & 9 & 17 & 12 & 46 & 11 & 534 \\
\hline Female & 17 & 20 & 30 & 32 & 35 & 62 & 70 & 80 & 86 & 88 & 86 & 60 & 666 \\
\hline Total & 86 & 75 & 68 & 212 & 95 & 80 & 89 & 89 & 103 & 100 & 132 & 71 & 1200 \\
\hline $\begin{array}{c}\text { Percentage } \\
\text { of male }\end{array}$ & 80.23 & 73.33 & 55.88 & 84.90 & 63.16 & 22.50 & 21.35 & 10.11 & 16.50 & 12.00 & 34.85 & 15.49 & 44.50 \\
\hline $\begin{array}{c}\text { Percentage } \\
\text { of female }\end{array}$ & 19.77 & 26.67 & 44.12 & 15.10 & 36.84 & 77.50 & 78.65 & 89.89 & 83.50 & 88.00 & 65.15 & 84.51 & 55.50 \\
\hline $\begin{array}{c}\text { Sex-ration } \\
\text { (male: } \\
\text { female) }\end{array}$ & $1: 0.25$ & $1: 0.36$ & $1: 0.79$ & $1: 0.18$ & $1: 0.58$ & $1: 3.44$ & $1: 3.38$ & $1: 8.88$ & $1: 5.06$ & $1: 7.30$ & $1: 1.87$ & $1: 5.45$ & $1: 1.25$ \\
\hline
\end{tabular}

The relative condition factor $(\mathrm{kn})$ was calculated for both sexes individually and combined. The $\mathrm{kn}$ values range from 0.9478 to 1.2709 in male, 0.6188 to 1.2007 female and 0.1061 to 1.2084 in combined sexes. The mean $\mathrm{kn}$ was calculated as $1.0131 \pm 0.0701,1.0081 \pm 0.1146$ and $0.9382 \pm 0.2179$ for male, female and combined sexes respectively.

From the year long study of size-frequency distribution of $R$. corsula it was found that the number of females were more than that of males which is supported by the findings of other authors working with different species such as Afroz et al. (1991) in case of Amblypharygodon mola, Mortuza and Mokarrama (2000) in case of Botia lohachata. The higher values of " $n$ " in females revealed that, the length-weight relationships might be affected by the general condition of appetite and gonadal contents of the fish.

Monthly and yearly percentage of male and female showed that the females dominated the natural population over the year (Table 1). Out of 1200 fishes, 534 were male and 666 were females. The total sex ratio was found to be 1:1.247.

The monthly sex ratio was insignificant at both $5 \%$ level of significance. Whereas, the total sex ratio over the year were significant at $5 \%$ level. Similar results were observed by Pillay (1958) in the winter Hilsa of the river Hoogly. Shafi et al. (1977) reported that the female of Hilsa ilisha predominated in the population in eight months of the year. Shafi and Quddus (1974) reported that the number of male and female $H$. ilisha varied considerable from month to month and the difference may largely be due the selective gear used. However, it is not clear which factors might be responsible in the fluctuation of male and female population distribution of $R$. corsula in Rajshahi region. 


\section{References}

Afroze S, Hossain M A and Parween S (1991) Notes on the size frequenceu distribution and length-weight relationship of freshwater fish. Amblypharygodon mola (Hamilton) (Cypriniformes : cyprinidae). Univ. j. Zool. Rajshahi Univ. 10\&11: 103-104.

Hile R (1936) Age and growth of cisco Leucicthyes artedi le Suercur in the lake of north eartern highland. S. Bull. U.S. Bur. Fish. 48:211-314.

Khan M (2000) Red book threatened fishes of Bangladesh (M Ameen, M A Islam and A Nishat eds). The world conservation Union, Bangladesh. pp 21-27

Le Cren E D (1951) The length-weight relationship and seasonal cycle in gonadal weight and condition in the perch, Perca fluviatilus. J. Anim. Ecol. 20: 201-219.

Martin W R (1949) The machanics of environmental control of body form in fishes. Univ. Toronto. Stud. Biol. 58: 1-91

Mortuza M G and Mokarrama N T (2000) Notes on the length-weight relationship and condition factor of mud loach Botia Iohachata (Chaudhuri) (Cypriniformes: Cobitidae). Univ .j. Zool. Rajshahi Univ. 19: 113-114.

Pillay T V R (1958) Biology of the Hilsa ilisha. Indian J. Fish. 5: 201-257.

Rahman A K (1989) Freshwater Fishes of Bangladesh. Zoological Society of Bangladesh. 177-180pp

Shafi M and Quddus M M A (1974) The length-weight relationship and condition factor in Hilsa ilisha (Hamilton) (Clupeiformes: Clupeidae). Bangladesh J. Zool. 2(2): 179-185.

Shafi M, Quddus M M A and Islam M N (1977) Studies on the weight, sex-ratio and fecundity of Hilsa ilisha (Hamilton Buchanan) of the river Meghna. J. Asiat. Soc. Bangladesh, Sci. 2: 52-58. 